\title{
Rozpoznawanie i leczenie chorych na chłoniaka Hodgkina
}

\section{Diagnosis and treatment of patients with Hodgkin lymphoma}

\author{
Tomasz Wróbel ${ }^{1}$, Bartosz Puła ${ }^{2}$ \\ ${ }^{1}$ Katedra i Klinika Hematologii, Nowotworów Krwi i Transplantacji Szpiku, Uniwersytet Medyczny, Wrocław \\ ${ }^{2}$ Klinika Hematologii, Instytut Hematologii i Transfuzjologii, Warszawa
}

\begin{abstract}
Streszczenie
Chtoniak Hodgkina (HL) należy do rzadkich nowotworów uktadu chtonnego pochodzenia B-komórkowego. Cechq charakterystyczna HL jest obecność niewielkiej liczby komórek nowotworowych otoczonych przez naciek komórek uktadu immunologicznego o immunosupresyjnym charakterze. Wyróżnia sie dwie postacie HL - postać klasyczna oraz postać guzkowa z przewaga limfocytów. Ocena stadium zaawansowania oraz czynników rokowniczych stanowi istotna kwestie $w$ doborze odpowiedniego leczenia opartego na chemioterapii oraz radioterapii. Rokowanie $w$ HL jest dobre, a odsetek wyleczeń siega 80\%. Okoto 10\% chorych (szczególnie w zaawansowanych stadiach) nie osiaga catkowitej remisji. U 20-30\% pacjentów, którzy poczatkowo uzyskali odpowiedź na leczenie, dochodzi do nawrotu choroby. Dla tej grupy chorych opcje terapeutyczna, poza chemioterapia, stanowia brentuksymab wedotin, inhibitory PD-1, przeszczepienie autologicznych lub allogenicznych krwiotwórczych komórek macierzystych lub udziat w badaniu klinicznym. W niniejszym artykule omówiono wytyczne diagnostyki i leczenia $H L$.
\end{abstract}

Słowa kluczowe: chłoniak Hodgkina, chemioterapia, przeszczepianie krwiotwórczych komórek macierzystych, prognoza, diagnostyka

Hematologia 2017; 8, 3: 163-176

\begin{abstract}
Hodgkin lymphoma (HL) is a rare B-cell derived lymphoid malignancy. Its typical feature is the presence of small number of tumor cells surrounded by immune cell infiltrate of immunosuppressive character. Two entities of HL are distinguished: classical HL and nodular lymphocyte predominant HL. Assessment of clinical advancement stage and prognostic factors is important for tailoring appropriate therapy based on chemotherapy and radiotherapy. Prognosis in HL is good with cure rate reaching almost $80 \%$. About $10 \%$ of patients (especially in advanced stages) does not achieve complete remission. In 20-30\% patients, who initially achieved a response, relapses occur. For these patients', besides chemotherapy, treatment with brentuximab vedotin, PD-1 inhibitors, autologous or allogeneic hematopoietic stem cell transplantation, or participation in clinical trial comprise potential therapy options. In this publication, we discuss the guidelines of diagnosis and treatment of HL.
\end{abstract}

Key words: Hodgkin lymphoma, chemotherapy, hematopoietic stem cell transplantation, prognosis, diagnostics

Hematologia 2017; 8, 3: 163-176

Adres do korespondencji: Tomasz Wróbel, Katedra i Klinika Hematologii, Nowotworów Krwi i Transplantacji Szpiku, Uniwersytet Medyczny, ul. Wybrzeże Pasteura 4, 50-367 Wrocław, tel. 71784 27 54, faks 713270963 ,

e-mail: tomasz_wrobel@wp.pl 


\section{Wprowadzenie}

Chłoniak Hodgkina (HL, Hodgkin lymphoma) jest chorobą nowotworową układu chłonnego. Charakteryzuje się obecnością olbrzymich nowotworowych komórek Reed-Sternberga (RS) o wielopłatowym jądrze oraz dużych jednojądrzastych komórek Hodgkina, które indukują odczynową proliferację, między innymi limfocytów, monocytów, histiocytów i makrofagów tworzących naciek ziarniczy (stąd dawna nazwa „ziarnica złośliwa”). Jest to unikatowa cecha ze względu na fakt, że główną masę nowotworu stanowią komórki mikrośrodowiska a nie same nowotworowe komórki RS [1,2].

\section{Epidemiologia}

Zachorowalność na HL ma charakter stały i w krajach rozwiniętych wynosi 2-3 przypadki/ $/ 100$ tys./rok, $z$ niewielką przewagą u mężczyzn (1,3:1). Obserwuje się dwa szczyty zachorowań - w 3. dekadzie życia i po 50. roku życia $\mathrm{W}$ krajach rozwijających się choroba częściej występuje w dzieciństwie [3].

\section{Patogeneza}

Etiologia choroby pozostaje niewyjaśniona. Brakuje również zdefiniowanych czynników ryzyka jej rozwoju. Komórki RS stanowią około $2 \%$ populacji komórek węzła chłonnego [2, 4]. Przełomem w badaniach nad etiopatogenezą HL było wyodrębnienie przez Diehla i wsp. linii komórkowej złożonej z komórek RS, a następnie odkrycie na tych komórkach obecności antygenu CD30 [5, 6]. Antygen CD30 jest transbłonowym białkiem pelniącym funkcję receptora cytokinowego $z$ grupy czynnika martwicy nowotworów $\alpha$ (TNF $\alpha$, tumor necrosis factor alpha). Antygen CD30 pozostaje najważniejszym markerem w diagnostyce HL (ale także chłoniaka anaplastycznego) [7]. Cechuje się niewielką ekspresją w zdrowych tkankach. Znakowanie anty-CD30 u chorych na HL wykazało, że komórki RS charakteryzują się większą, niż początkowo sądzono, zmiennością morfologiczną, a ich odsetek w nacieku ziarniczym może sięgać nawet $30 \%$. Barwienie anty-CD30 i anty-CD20 pozwoliło także na wyodrębnienie dwóch podtypów histologicznych HL, w tym postaci klasycznych (cHL, classical HL) CD30+, CD20- oraz postaci guzkowej z przewagą limfocytów (NLPHL, nodular lymphocyte predominant HL) CD30-, CD20 + [8-10].

Odkrycie antygenu CD30 i wyprodukowanie przeciwciał anty-CD30 umożliwiło izolację komó- rek RS i ich analizę molekularną. Obecnie wiadomo, że komórki te mają charakter monoklonalny i w $98 \%$ przypadków wywodzą się z limfocytów B (co potwierdzono $\mathrm{w}$ badaniach rearanżacji genów łańcuchów ciężkich immunoglobulin) [11-13]. Komórki RS, mimo że wywodzą się z limfocytów $\mathrm{B}$, nie są $z$ dolne do produkcji immunoglobulin ze względu na brak czynników transkrypcyjnych OCT-2 i BOB.1 $[14,15]$. Cechują się także wysoką ekspresją jądrowego czynnika transkrypcyjnego $\kappa \mathrm{B}$ $(\mathrm{NF}-\kappa \mathrm{B}$, nuclear factor $\kappa B$ ) oraz aktywnością szlaku NOTCH $[16,17]$.

Wykazano pewne zależności epidemiologiczne, które mogą się wiązać $z$ wystąpieniem choroby [3]. U rodzeństwa tej samej płci chorych na HL ryzyko rozwoju choroby jest 10-krotnie wyższe $[9,18]$. W przypadku bliźniąt jednojajowych chorych na HL ryzyko rozwoju choroby u rodzeństwa jest 99-krotnie większe niż u bliźniąt dwujajowych $[19,20]$. Ponadto wyższe ryzyko zachorowania wiąże się $z$ wyższym statusem socjoekonomicznym i mniejszą liczbą rodzeństwa, co prawdopodobnie wynika $z$ mniejszej ekspozycji na czynniki zakaźne w dzieciństwie. Zależności te wskazują na predyspozycje genetyczne i/lub znaczenie czynników infekcyjnych lub środowiskowych w etiologii choroby. U osób palących tytoń częstość zachorowań na HL jest około 2-krotnie większa [3, 9].

Badania epidemiologiczne i serologiczne wskazują na związek zakażenia wirusem Epstein-Barr (EBV, Epstein-Barr virus) z rozwojem HL. Genom EBV jest wykrywany w 20-80\% materiału histologicznego $z$ węzłów chłonnych [21, 22]. Dane epidemiologiczne wskazują na większą częstość zachorowań na HL wśród osób zakażonych ludzkim wirusem nabytego niedoboru odporności (HIV, human immunodeficiency virus) [23]. U pacjentów z HIV choroba występuje zazwyczaj w stadiach zaawansowanych, nierzadko w lokalizacji pozawęzłowej oraz charakteryzuje się gorszym rokowaniem mimo leczenia $[24,25]$.

\section{Diagnostyka}

\section{Objawy podmiotowe i przedmiotowe}

Chłoniak Hodgkina zajmuje głównie węzły chłonne. Ich niebolesne powiększenie jest podstawowym objawem. Ponad $80 \%$ pacjentów zgłasza się do lekarza $z$ powodu limfadenopatii obwodowej zlokalizowanej powyżej przepony, często $z$ towarzyszącym powiększeniem węzłów chłonnych przedniego śródpiersia. Najczęściej w przebiegu HL dochodzi do zajęcia węzłów chłonnych szyjnych, nadobojczykowych i pachowych, rzadziej 
pachwinowych. Śledziona jest nacieczona w około $30 \%$ przypadków. Powiększenie węzłów chłonnych o lokalizacji wyłącznie podprzeponowej dotyczy jedynie 10-20\% chorych. Układowa limfadenopatia występuje rzadko, podobnie nieczęste są zajęcie pierścienia Waldeyera, tylnego śródpiersia czy węzłów krezkowych [2, 9].

Powiększeniu węzłów chłonnych często nie towarzyszą żadne inne dolegliwości. Objawy systemowe, takie jak gorączka, nocne poty oraz zmniejszenie masy ciała ( $>10 \% \mathrm{w}$ ciągu 6 mies.), występują u około $30 \%$ pacjentów. Chorobie może też towarzyszyć uporczywy świąd skóry. U niektórych pacjentów po spożyciu alkoholu pojawia się ból zajętych węzłów chłonnych. Objawy systemowe częściej występują u starszych chorych i wiążą się $z$ niekorzystnym rokowaniem. Uważa się, że jednoczesne występowanie gorączki i zmniejszenia masy ciała jest rokowniczo bardziej niekorzystne niż obecność samej nadpotliwości. Duża masa węzłowa w śródpiersiu może powodować uporczywy kaszel, duszność oraz objawy zespołu żyły głównej górnej [2, 9].

Lokalizacja pozawęzłowa HL jest rzadka. Choroba może się wtedy szerzyć przez ciągłość lub rozsiewać drogą krwionośną. Do najczęściej zajmowanych narządów pozalimfatycznych należą: płuca, wątroba, szpik kostny, kości [9].

\section{Patomorfologia, biologia molekularna,}

kryteria rozpoznania oraz różnicowanie

Podstawą rozpoznania pozostaje ocena histopatologiczna węzła chłonnego lub innej nacieczonej tkanki. Biopsja aspiracyjna nie jest adekwatną metodą diagnostyczną ze względu na mały odsetek komórek RS znajdujących się w masie guza [2, 9]. Podstawą klasyfikacji są różnice w morfologii komórek nowotworowych oraz w otaczających je środowiskach. Od 1994 roku wyróżnia się dwa podstawowe typy choroby - postać klasyczną (cHL, classical Hodgkin lymphoma) obejmującą niemal 95\% przypadków oraz znacznie rzadszy podtyp guzkowy $z$ przewagą limfocytów (NLPHL, nodular lymphocyte-predominant Hodgkin lympho$m a)$ stwierdzany w około $5 \%$ przypadków $[1,2]$.

Histopatologicznie typ klasyczny HL, ze względu na zróżnicowanie środowiska komórkowego otaczającego komórki nowotworowe, dzieli się na cztery podtypy $[2,9]$ :

- stwardnienia guzkowego (NS, nodular sclerosis; 60-80\% rozpoznań) — stwierdzany głównie u młodych osób oraz dorosłych, choroba zajmuje przede wszystkim węzły chłonne szyjne, nadobojczykowe oraz śródpiersiowe;
- postaci mieszanokomórkowej (MC, mixed cellularity; 15-20\% rozpoznań) - częściej spotykany u dzieci oraz starszych pacjentów, choroba jest częściej stwierdzana w zaawansowanym stadium oraz charakteryzuje się gorszym rokowaniem $\mathrm{w}$ porównaniu $\mathrm{z} \mathrm{NS}$;

- postaci bogatej w limfocyty (LR, lymphocyte-rich; 5\% rozpoznań) - morfologicznie choroba przypomina postać NLPHL, jednak immunofenotyp komórek RS odpowiada temu spotykanemu w klasycznej;

- postaci ubogiej w limfocyty (LD, lymphocyte-depleted; < $1 \%$ rozpoznań) - występuje głównie u osób starszych oraz pacjentów z zaburzeniami odporności, choroba często przebiega $z$ objawami ogólnymi oraz rzadko zajmuje obwodowe węzły chłonne, rokowanie jest gorsze niż w NS. Podtyp LD jest obecnie coraz rzadziej rozpoznawany - część $z$ dotychczas zdiagnozowanych przypadków spełniała kryteria rozpoznania chłoniaka anaplastycznego.

W przypadku NLPHL nie stwierdza się typowych komórek RS, natomiast w podtypie tym stwierdza się naciek dużych komórek limfocytarno-histiocytarnych (L\&H, lymphocytic and histiocytic cells). Komórki te, w odróżnieniu od komórek RS, charakteryzują się ekspresją antygenu CD20 przy braku eskspresji CD30 [8, 10]. Typ NLPHL częściej występuje u mężczyzn $z$ obecnością objawów ogólnych. Choroba $z$ reguły zajmuje węzły chłonne szyjne, rzadko śródpiersie. W odróżnieniu od cHL ma łagodny przebieg, jednak obserwuje się późne nawroty po zastosowanym leczeniu [10,26].

Obraz histologiczny cHL jest bardzo charakterystyczny. Chłoniak Hodgkina powinien być różnicowany $z$ chłoniakami nie-Hodgkina (NHL, non-Hodgkin lymphoma), takimi jak pierwotny chłoniak śródpiersia B-komórkowy, chłoniaki rozlane $z$ dużych komórek $\mathrm{B}$, chłoniak $\mathrm{z}$ dużych komórek anaplastyczny.

\section{Badania laboratoryjne i obrazowe}

W ramach badań laboratoryjnych należy wykonać morfologię krwi obwodowej $z$ rozmazem (często obserwuje się granulocytozę, limfopenię oraz nadpłytkowość i niedokrwistość), a także ocenić wartość odczynu Biernackiego (OB), która ma znaczenie rokownicze we wczesnych stadiach choroby oraz koreluje $z$ odpowiedzią na leczenie i z nawrotem choroby. W każdym przypadku należy wykonać badania biochemiczne wydolności wątroby i nerek, oznaczyć aktywność dehydrogenazy mleczanowej (LDH, lactate dehydrogenase), stężenie beta $_{2}$-mikroglobuliny, proteinogram, stężenie 
białka C-reaktywnego (CRP, C-reactive protein), wykonać badania wirusologiczne w kierunku zakażenia wirusem zapalenia wątroby typu B i C oraz HIV, a także elektrokardiografię i echokardiografię $w$ celu oceny frakcji wyrzutowej serca. Ponadto, $\mathrm{u}$ osób starszych oraz $\mathrm{w}$ określonych przypadkach, wskazane jest wykonanie badania spirometrycznego.

Obecnie standardem w badaniach obrazowych HL w ocenie zaawansowania choroby jest badanie pozytonowej tomografii emisyjnej PET (positron emission tomography) $[27,28]$. Pozwala ono wykryć węzłowe i pozawęzłowe lokalizacje HL niedostępne w badaniu przedmiotowym. Wykonanie badania PET przed wdrożeniem leczenia pozwala także na użycie tej metody do porównania zmian aktywności metabolicznej narządów zajętych przez HL, w czasie terapii (wczesna ocena) oraz po zakończeniu leczenia [27, 28]. W ocenie badania wykorzystuje się 5-punktową skalę Deauville (tab. 1) [27, 28].

Tabela 1. Pięciopunktowa skala pozytonowej tomografii emisyjnej (PET) (kryteria Deauville) (źródła [27, 28])

Table 1. Five-point positron emission tomography (PET) scale (Deauville criteria) (sources $[27,28]$ )

\begin{tabular}{|l|c|}
\hline Wynik badania PET — wychwyt FDG & Punktacja \\
\hline Bez wychwytu FDG powyżej tła & 1 \\
\hline $\begin{array}{l}\text { Wychwyt FDG poniżej lub równy wychwy- } \\
\text { towi śródpiersia }\end{array}$ & 2 \\
\hline $\begin{array}{l}\text { Wychwyt FDG powyżej wychwytu śródpier- } \\
\text { sia, ale poniżej lub równy z wychwytem } \\
\text { wątroby }\end{array}$ & 3 \\
\hline $\begin{array}{l}\text { Wychwyt FDG umiarkowany, powyżej wy- } \\
\text { chwytu wątroby }\end{array}$ & 4 \\
\hline $\begin{array}{l}\text { Wychwyt FDG znacznie wyższy od wychwy- } \\
\text { tu wątroby }\end{array}$ & 5 \\
\hline
\end{tabular}

FDG (fluorodeoxyglucose) - fluorodeoksyglukoza
W przypadku braku wychwytu znacznika w obrębie szpiku kostnego można odstąpić od wykonania jego inwazyjnych badań (mielogram, trepanobiopsja). $\mathrm{W}$ przeciwnym razie zaleca się ich wykonanie. Rezonans magnetyczny wykonuje się rzadko, głównie służy do różnicowania zmian naciekowych w tkankach miękkich oraz w obrębie ośrodkowego układu nerwowego (OUN). Badania endoskopowe przeprowadza się jedynie $\mathrm{w}$ przypadku podejrzenia zmian w obrębie przewodu pokarmowego lub układu oddechowego.

\section{Określenie stopnia zaawansowania}

Rozpoznanie histopatologiczne HL musi być w każdym przypadku uzupełnione oceną stopnia zaawansowania klinicznego (CS, clinical stage), której podstawy opracowano po raz pierwszy na konferencji w Ann Arbor w 1971 roku, z modyfikacją w Cotswolds w 1989 roku [29, 30]. Według tej klasyfikacji stopień zaawansowania obejmuje liczbę i lokalizację zajętych węzłów chłonnych lub narządów pozalimfatycznych (oznaczane cyframi rzymskimi), obecność lub nieobecność objawów systemowych, określanych odpowiednio literą B lub A, oraz uwzględnia dodatkowe litery - E w przypadku zajęcia narządu pozalimfatycznego przez ciągłość i X w przypadku obecności zmiany masywnej. Ta ostatnia sama w sobie stanowi powszechnie akceptowany niekorzystny czynnik rokowniczy. W śródpiersiu stwierdza się ją, gdy rozmiar nacieku przekracza $1 / 3$ wymiaru poprzecznego klatki piersiowej na wysokości Th5-6, a w innych lokalizacjach — gdy jakikolwiek wymiar poprzeczny zmiany przekracza $10 \mathrm{~cm}$. Obecnie stopień zaawansowania HL określa się według kryteriów zaproponowanych przez Międzynarodową Grupę Roboczą w Lugano (tab. 2) [28].

Tabela 2. Klasyfikacja stopnia zaawansowania chłoniaka Hodgkina według klasyfikacji z Lugano (źródło [28])

Table 2. Advancement scale of Hodgkin lymphoma according to the Lugano classification (source [28])

\begin{tabular}{|c|l|l|}
\hline Stopień & Zmiany węzłowe & Zmiany pozawęzłowe (E) \\
\hline I & Jeden węzeł chłonny lub grupa węzłów przyległych & $\begin{array}{l}\text { Pojedyncza zmiana węzłowa bez zajęcia węzłów } \\
\text { chłonnych }\end{array}$ \\
\hline II & $\begin{array}{l}\text { Dwie lub więcej grup węzłowych po tej samej stronie } \\
\text { przepony }\end{array}$ & $\begin{array}{l}\text { Stopień I lub II w odniesieniu do zmian węzłowych } \\
\text { z ograniczonym umiejscowieniem pozawęzłowym } \\
\text { przez ciągłość }\end{array}$ \\
\hline III & $\begin{array}{l}\text { Węzły po obu stronach przepony lub węzły powyżej } \\
\text { przepony i zajęcie śledziony }\end{array}$ & Nie dotyczy \\
\hline IV & $\begin{array}{l}\text { Dodatkowe zajęcie narządu pozalimfatycznego niesą- } \\
\text { siadującego z zajętymi węzłami chłonnymi }\end{array}$ & Nie dotyczy \\
\hline
\end{tabular}


Informacje dotyczące wyjściowego stanu zaawansowania choroby są bardzo ważne dla wyboru optymalnych metod leczenia. W tym celu u każdego chorego $\mathrm{z}$ rozpoznaniem HL należy przeprowadzić dokładne badania podmiotowe, przedmiotowe, laboratoryjne i obrazowe. Szczegółowy wywiad powinien uwzględnić obecność objawów ogólnych.

W badaniu przedmiotowym szczególną uwagę należy zwrócić na ocenę obwodowych węzłów chłonnych, obecność płynów w jamach ciała, występowanie cech zespołu żyły głównej górnej, hepatosplenomegalię, odnotowanie stopnia sprawności według skali Karnofsky'ego i/lub Swiatowej Organizacji Zdrowia (WHO, World Health Organization).

\section{Czynniki predykcyjne i prognostyczne}

Najważniejszym czynnikiem rokowniczym w HL jest stopień zaawansowania choroby [31, 32]. Dla stadiów wczesnych opracowano dodatkowe czynniki prognostyczne przedstawione $\mathrm{w}$ tabeli 3. Zgodnie $z$ nimi wyróżnia się trzy grupy rokownicze (postaci wczesnej o korzystnym rokowaniu, postaci wczesnej o niekorzystnym rokowaniu oraz postaci zaawansowanej) [9, 33, 34]. Niektóre ośrodki, planując terapię $\mathrm{u}$ chorych $\mathrm{w}$ stadiach wczesnych $z$ chorobą bulky, stosują protokoły jak w przypadku stadiów zaawansowanych (tab. 3).

U chorych $z$ zaawansowaną postacią HL dodatkowym narzędziem rokowniczym okazał się Międzynarodowy Wskaźnik Prognostyczny (IPS, International Prognostic Score) [35]. Uwzględnia on siedem czynników rokowniczych przedstawionych $\mathrm{w}$ tabeli 4. Obecność każdego $z$ nich niezależnie wiąże się $z$ krótszym o około $8 \%$ czasem wol-
Tabela 4. Obciążające czynniki rokownicze według Międzynarodowego Wskaźnika Prognostycznego dla zaawansowanej postaci chłoniaka Hodgkina (źródło [35])

Table 4. Poor prognostic factors according to International Prognostic Score for advanced type of Hodgkin lymphoma (source [35])

\begin{tabular}{|l|l|}
\hline Parametr & Wartość/opis \\
\hline Stężenie albumin w surowicy & $<40 \mathrm{~g} / \mathrm{l}$ \\
\hline Stężenie hemoglobiny & $<10,5 \mathrm{~g} / \mathrm{dl}$ \\
\hline Płeć & Męska \\
\hline Wiek & $>45$ lat \\
\hline Stadium zaawansowania & IV \\
\hline Liczba leukocytów & $>15 \mathrm{G} / \mathrm{l}$ \\
\hline Liczba limfocytów & $<0,6 \mathrm{G} /$ lub 8\% wartości \\
& leukocytozy \\
\hline
\end{tabular}

nym od progresji choroby (PFS, progression-free survival) i całkowitym czasem przeżycia (OS, overall survival). Zgodnie $z$ IPS chorych klasyfikuje się do dwóch grup rokowniczych - niskiego ( $\leq 2$ niekorzystne czynniki) oraz wysokiego ryzyka ( $>2$ niekorzystne czynniki) [35].

Obecnie praktyczne zastosowanie IPS wydaje się ograniczone. Coraz większe znaczenie prognostyczne zyskuje natomiast badanie PET - w zaawansowanym HL dodatni wynik badania PET wykonany po 2 cyklach ABVD (adriamycyna, bleomycyna, winblastyna, dakarbazyna) jest niezależnym od IPS niekorzystnym czynnikiem prognostycznym [36, 37]. Ze względu na niekorzystne rokownicze znaczenie dodatniego wyniku badania PET po 2 cyklach chemioterapii (CHT)

Tabela 3. Grupy chorych na chłoniaka Hodgkina (HL) zależnie od stopnia zaawansowania i czynników rokowniczych zgodnie z kryteriami zaproponowanymi przez EORTC (European Organisation for Research and Treatment of Cancer), GELA (Groupe d'Étude des Lymphomes de l'Adulte) i GHLSG (German Hodgkin Lymphoma Study Group)

Table 3. Hodgkin lymphoma (HL) patient group classification based on clinical advancement scale and presence of prognostic factors according to the criteria proposed by EORTC (European Organisation for Research and Treatment of Cancer), GELA (Groupe d'Étude des Lymphomes de l'Adulte) and GHLSG (German Hodgkin Lymphoma Study Group)

\begin{tabular}{|l|l|l|}
\hline Grupy chorych & EORTC/GELA & GHSG \\
\hline $\begin{array}{l}\text { Z wczesną postacią HL o korzystnym rokowa- } \\
\text { niu bez czynników ryzyka }\end{array}$ & $\begin{array}{l}\text { CS I-II bez czynników ryzyka (nad- } \\
\text { przeponowa) }\end{array}$ & CS I-II bez czynników ryzyka \\
\hline $\begin{array}{l}\text { Z wczesną postacią HL o niekorzystnym roko- } \\
\text { waniu z czynnikami ryzyka (pośrednia) }\end{array}$ & $\begin{array}{l}\text { CS I-II z } \geq 1 \text { czynnikiem ryzyka } \\
\text { (nadprzeponowa) }\end{array}$ & $\begin{array}{l}\text { CS I, IIA z } \geq 1 \text { czynnikiem ryzyka } \\
\text { CS IIB z C/D, ale bez A/B }\end{array}$ \\
\hline Z zaawansowaną postacią HL & CS III-IV & CS IIB z A/B CS III-IV \\
\hline Czynniki ryzyka dla wczesnych postaci & $\begin{array}{l}\text { - Duże śródpiersie } \\
\text { Wiek } \geq 50 \text { lat } \\
\text { Podwyższony OB } \\
\text { - Zajęcie } \geq 4 \text { regionów }\end{array}$ & $\begin{array}{l}\text { - Duże śródpiersie } \\
\text { Lokalizacja pozawęzłowa } \\
\text { Podwyższony OB } \\
\text { Zajęcie } \geq 3 \text { regionów }\end{array}$ \\
\hline
\end{tabular}

CS (clinical stage) - stopień zaawansowania klinicznego; OB — odczyn Biernackiego 
istnieją obecnie przesłanki, aby u tych chorych we wczesnych stadiach leczonych według schematu ABVD rozważyć intensyfikację leczenia zgodnie ze schematem BEACOPP (bleomycyna, etopozyd, adriamycyna, cyklofosfamid, winkrystyna, prokarbazyna, prednizon) w dawkach eskalowanych (BEACOPPesc, BEACOPP escalated) $\mathrm{z}$ następową radioterapią (RTH, radiotherapy) [38-40].

\section{Leczenie}

Najważniejszym czynnikiem w planowaniu leczenia jest stadium zaawansowania choroby, $z$ uwzględnieniem czynników prognostycznych. Należy podkreślić, że wszyscy pacjenci, niezależnie od stadium i rokowania, powinni być poddani terapii $z$ intencją wyleczenia. U młodych mężczyzn przed rozpoczęciem CTH należy rozważyć zamrożenie nasienia.

\section{Leczenie pierwszej linii}

Ważną rolę w obniżaniu ryzyka nawrotu lub pierwotnej oporności odgrywa właściwe prowadzenie leczenia pierwszej linii. Szczególnie istotne jest dobranie odpowiedniego zestawu cytostatycznego. Bardzo ważne jest zachowanie określonej w protokole intensywności dawki. Stosowanie czynnika pobudzającego wzrost kolonii granulocytów (G-CSF, granulocyte colony-stimulating factor) pozwala uniknąć opóźniania cykli CTH lub zmniejszania dawek cytostatyków. W uzasadnionych przypadkach (wczesne stadia HL i duża masa guza) należy prowadzić leczenie skojarzone $z$ zastosowaniem CTH i uzupełniającej RTH. Trzeba dołożyć szczególnych starań, aby we właściwy sposób monitorować leczenie poprzez umiejętne wykorzystanie wczesnej oceny PET w połączeniu $\mathrm{z}$ tomografią komputerową (CT, computed tomography; PET-CT). Przeprowadzenie tych badań po 2 kursach terapii pozwala wyodrębnić chorych $z$ suboptymalną odpowiedzią lub brakiem odpowiedzi na leczenie. Wyodrębnienie chorych o dobrym rokowaniu na podstawie wczesnej oceny PET-CT pozwoliłoby na indywidualizację intensywności leczenia (możliwość odstąpienia od RTH, ograniczenie liczby cykli CTH, odstąpienie od stosowania bleomycyny). Terapia zależna od wczesnego wyniku PET - zarówno w stadiach wczesnych, jak i zaawansowanych - pozostaje obecnie przedmiotem badań klinicznych i nie powinna być stosowana w rutynowej praktyce klinicznej [38].

\section{Chorzy w stadium wczesnym i pośrednim}

$\mathrm{W}$ tej grupie chorych leczeniem $z$ wyboru jest CTH skojarzona $z$ RTH. Zastosowanie wyłącznie
RTH we wczesnym stadium HL okazało się postępowaniem mniej korzystnym niż terapia skojarzona [41]. Badania grupy niemieckiej (HD10) wskazują, że u chorych $z$ grupy niskiego ryzyka (stadium wczesne choroby wg GHLSG [German Hodgkin Lymphoma Study Group] i EORTC/GELA [European Organisation for Research and Treatment of Cancer/Groupe d'Étude des Lymphomes de l'Adulte]) wystarcza zastosowanie 2 cykli ABVD i RTH okolic pierwotnie zajętych (IF-RT, involved-field radiotherapy) w dawce 20 Gy [42]. Natomiast u chorych $z$ grupy niekorzystnego ryzyka (stadium pośrednie choroby wg GHLSG i EORTC/GELA) powinno się stosować 4 cykle ABVD i IF-RT w dawce $30 \mathrm{~Gy}$ [43]. Alternatywą w tej grupie chorych są 2 cykle według schematu BEACOPPesc i 2 cykle zgodnie ze schematem ABVD, a następnie IF-RT w dawce 30 Gy [44]. Radioterapia uzupełniająca pozostaje standardem leczenia chorych $z$ dużą masą guza (bulky), zlokalizowaną przeważnie w śródpiersiu.

Możliwość ograniczenia leczenia do samej CTH u chorych $z$ negatywną wczesną oceną PET jest przedmiotem badań klinicznych. W wybranych przypadkach (przeciwwskazania do RTH) w leczeniu wczesnych stadiów HL możliwe jest stosowanie samej CTH według schematu ABVD (4-6 cykli). Jakkolwiek w ostatnich latach obserwuje się tendencję do ograniczenia dawek i zmniejszania zakresu naświetlanych pól nawet do RTH na zajęte węzły (IN-RT, involved-nodes radiotherapy), to należy podkreślić, że wyniki dotychczasowych badań nie uzasadniają całkowitego odstąpienia od RTH we wczesnych stadiach HL [39, 40]. Stosowanie napromieniania skojarzonego $z$ CTH wiąże się $z$ jednej strony ze zwiększonym ryzykiem wtórnych nowotworów oraz z nasileniem kardiotoksyczności [45], $z$ drugiej strony natomiast istotnie obniża ryzyko niepowodzenia leczenia, a tym samym konieczność stosowania terapii ratunkowej [39, 40].

\section{Chorzy w stadiach zaawansowanych}

W leczeniu chorych w stadiach zaawansowanych należy zastosować systemową chemioterapię w oparciu o protokół ABVD [46-48] lub BEACOPPesc $[49,50]$. W wynikach metaanalizy obejmującej ponad 10 tys. chorych z 14 badań klinicznych $z$ zastosowaniem różnych cykli CTH wykazano, że w leczeniu pierwszej linii zaawansowanych postaci HL schemat BEACOPPesc wykazuje przewagę nad ABVD w odniesieniu do OS o 10\% [51]. Biorąc pod uwagę skuteczność przeciwnowotworową, protokó1 BEACOPPesc pozwala na uzyskanie 5-letniego PFS w $90 \%$ przypadków, co jest wynikiem lepszym o około $20 \%$ od uzyskiwanego w przypadku stoso- 
wania protokołu ABVD. Korzyści w odniesieniu do OS są jednak mniej wyraźne głównie ze względu na możliwość efektywnego leczenia wznowy. $\mathrm{W}$ randomizowanym badaniu włoskim, w którym porównywano nie tylko leczenie pierwszej linii (ABVD $v$. BEACOPPesc), ale także uwzględniano skuteczność CTH ratunkowej z megachemioterapią wspomaganą przeszczepieniem autologicznych krwiotwórczych komórek macierzystych (auto-HSCT, autologous hematopoietic stem cell transplantation), nie wykazano różnic w zakresie OS między badanymi protokołami [52]. Dlatego w wyborze między ABVD a BEACOPPesc klinicysta powinien wziąć po uwagę większą skuteczność przeciwnowotworową tego ostatniego. Należy jednak pamiętać, że skuteczność ta wiąże się z toksycznością wczesną (głównie hematologiczną) oraz późną (wtórne nowotwory, szczególnie układu krwiotwórczego) $[53,54]$. U młodszych chorych problemem pozostaje toksyczność gonadalna BEACOPPesc $[55,56]$. Schemat BEACOPPesc nie powinien być stosowany u chorych powyżej 60 . roku życia ze względu na dużą toksyczność hematologiczną [53, 54].

W postaciach zaawansowanych HL standardem leczenia pozostaje protokół ABVD, który jest relatywnie bezpieczny i pozwala na prowadzenie terapii ambulatoryjnej. Należy wziąć pod uwagę, że większa skuteczność protokołu BEACOPPesc wiąże się $z$ nasileniem toksyczności. Racjonalne wydaje się rozważenie zastosowania BEACOPPesc u chorych młodszych $(<60$. rż.) oraz obciążonych wysokim ryzykiem według IPS $(\geq 4)$.

W przypadku rozpoczęcia leczenia według schematu ABVD zaleca się podanie 2 cykli leczenia $z$ następową oceną w PET. W przypadku odpowiedzi na leczenie (1-3 pkt. w skali Deauville) leczenie należy kontynuować do łącznie 6-8 cykli. Natomiast w przypadku braku odpowiedzi (4 lub 5 pkt. w skali Deauville) należy rozważyć intensyfikację leczenia, na przykład w oparciu o schemat BEACOPPesc (4 cykle).

Rola uzupełniającej RTH w leczeniu zaawansowanych postaci HL również pozostaje przedmiotem kontrowersji. Rutynowo stosuje się ją w przypadkach wyjściowej dużej masy guza (bulky) lub na zmiany resztkowe $(>1,5 \mathrm{~cm}$ u chorych leczonych ABVD) w dawce 30-36 Gy. Według ostatnich danych uzupełniająca RTH nie jest konieczna w przypadku obecności zmian resztkowych niewykazujących wychwytu znacznika w badaniu PET u chorych leczonych według schematu BEACOPPesc [49].

U chorych na NLPHL w stadium zaawansowania IA nieobciążonych czynnikami ryzyka można zastosować wyłącznie IF-RT w dawce 30 Gy [57]. W przypadku pozostałych stadiów leczenie powinno być podobne jak u chorych na cHL $[9,58]$. Ze względu na ekspresję antygenu CD20 na komórkach L\&H w leczeniu chorych na postacie zaawansowane stosuje się rytuksymab, jednak brakuje jednoznacznych wyników badań randomizowanych, w których potwierdzono by korzyść $z$ takiego postępowania [59, 60].

\section{Choroba oporna lub nawrotowa}

Megachemioterapia $z$ auto-HSCT jest standardem postępowania w przypadku nawrotowej/opornej postaci HL. Przed transplantacją konieczne jest zastosowanie leczenia ratunkowego. Optymalny protokół CTH drugiej linii powinien się cechować skutecznością przeciwnowotworową i niską toksycznością, szczególnie wobec krwiotwórczych komórek macierzystych, umożliwiając tym samym ich mobilizację i późniejsze przeszczepienie. Wobec braku badań randomizowanych trudno wskazać protokół CTH, który miałby zdecydowaną przewagę nad pozostałymi. Do najczęściej stosowanych w praktyce klinicznej zalicza się schematy oparte na cisplatynie, takie jak DHAP (cisplatyna, arabinozyd cytozyny, deksametazon) [61], ESHAP (etopozyd, metylprednizolon, arabinozyd cytozyny, cisplatyna) [62, 63], ASHAP (doksorubicyna, metylprednizolon, arabinozyd cytozyny, cisplatyna) [64], ICE (ifosfamid, karboplatyna, etopozyd) [62], oraz na gemcytabinie: IGEV (ifosfamid, gemcytabina, winorelbina) [65], GVD (gemcytabina, winorelbina, pegylowana doksorubicyna) [66], GDP (gemcytabina, deksametazon, cisplatyna) [67]. Ich toksyczność jest podobna, głównie hematologiczna oraz dotycząca przewodu pokarmowego (nudności, wymioty).

Dobór leczenia drugiej linii zależy od doświadczenia ośrodka, stanu klinicznego pacjenta, obecności chorób wspólistniejących (np. upośledzenie funkcji nerek ogranicza zastosowanie cisplatyny), rodzaju stosowanego leczenia pierwszej linii (skumulowana dawka antracyklin i bleomycyny) oraz od poprzedzającej RTH. Chorzy powinni być poddani ocenie po 2 kursach CTH. W przypadku braku odpowiedzi (4-5 pkt. w skali Deauville) należy zmienić protokól. W przypadku uzyskania odpowiedzi po zastosowaniu $2-4$ cykli leczenia ratunkowego chorego należy zakwalifikować do wysokodawkowanej CTH, najczęściej według schematu BEAM (karmustyna, etopozyd, arabinozyd cytozyny, melfalan), wspomaganej auto-HSCT [68-71]. Ta metoda leczenia jest obarczona znaczną toksycznością (szczególnie 
w grupie starszych chorych), jednak pozwala na uzyskanie trwałych odpowiedzi u około połowy chorych $z$ nawrotem $[9,72]$.

Do negatywnych czynników rokowniczych $u$ chorych $z$ nawrotem/opornych przed auto-HSCT zalicza się między innymi wznowę w czasie krótszym niż 12 miesięcy, stadium kliniczne III/IV Ann Arbor w nawrocie oraz wznowę w miejscach uprzednio napromienianych. Szczególnie źle rokującą grupą są pacjenci pierwotnie oporni na CTH. Zastosowanie wysokodawkowanej CTH $z$ auto-HSCT umożliwia wyleczenie $50-60 \%$ chorych $z$ nawrotową/oporną postacią HL [9]. Najlepsze wyniki uzyskuje się u osób $z$ późną wznową (> 12 miesięcy) i z zachowaną chemiowrażliwością. Istnieją przesłanki kliniczne wskazujące, że podwójne auto-HSCT może być skuteczne w wybranej grupie chorych $z$ nawrotem o niekorzystnym ryzyku (pacjenci pierwotnie oporni, chorzy $z$ nawrotem i obciążeni $\geq 2$ czynnikami ryzyka, pacjenci PET+ po CTH ratunkowej) [73].

Istotnym problemem klinicznym pozostają chorzy, u których doszło do wznowy po auto-HSCT. Rokowanie w tej grupie jest niekorzystne $z$ medianą przeżycia nieprzekraczającą 2 lat. Przeszczepienie allogenicznych krwiotwórczych komórek macierzystych (allo-HSCT, allogeneic hematopoietic stem cell transplantation) $\mathrm{u}$ chorych na HL pozostaje przedmiotem kontrowersji, głównie ze względu na wysoką śmiertelność okołoprzeszczepową (TRM, transplant-related mortality) sięgającą nawet $50 \%$ przy CTH mieloablacyjnej [74]. Wprowadzenie kondycjonowania o zredukowanej intensywności (RIC, reduced-intensity conditioning) pozwala na uzyskanie długoletnich przeżyć u 20-30\% chorych [74-76]. Przyjmuje się, że metodę tę należy wykorzystać po wcześniejszym udokumentowaniu niepowodzenia auto-HSCT [9].

Radioterapii nie powinno się stosować w monoterapii nawrotowych/opornych zaawansowanych postaci HL. Może jednak stanowić opcję terapeutyczną u chorych ze zlokalizowaną późną wznową, bez objawów ogólnych i innych wymienionych czynników ryzyka. W tej grupie RTH jako jedyna forma leczenia pozwala na osiagnięcie ponad $70 \%$ CR i ponad 50\% 5-letnich przeżyć. Radioterapia może być też wykorzystywana w leczeniu skojarzonym do eliminacji zmian resztkowych po CTH ratunkowej [77].

Istnieje grupa chorych, u których ze względu na wiek lub schorzenia współistniejące istnieją przeciwwskazania do auto-HSCT i/lub allo-HSCT. $\mathrm{W}$ tej grupie stosuje się konwencjonalną CTH, ewentualnie w skojarzeniu z RTH. U chorych z póź- nym nawrotem można ponownie wykorzystać leki zastosowane w leczeniu pierwszej linii. W przypadku braku możliwości wykonania allo-HSCT w nawrocie po auto-HSCT alternatywą pozostaje konwencjonalna chemioterapia $\mathrm{w}$ oparciu o winorelbinę lub gemcytabinę, jednak odpowiedź na leczenie jest krótka [78, 79]. Inną opcją jest podanie nowych leków, najlepiej w ramach kontrolowanych badań klinicznych.

\section{Nowe leki w leczeniu chłoniaka Hodgkina}

Brentuksymab wedotin (BV, brentuximab vedotin) jest przeciwciałem chimerycznym skierowanym przeciwko cząsteczce CD30 i powiązanym kowalencyjnie $z$ inhibitorem mikrotubuli - auristatyną E jednometylowaną (MMAE, monomethyl auristatin $E$ ) [80]. U chorych na nawrotowego lub opornego HL po niepowodzeniu wysokodawkowanej CTH wspomaganej auto-HSCT ogólny odsetek odpowiedzi po zastosowaniu BV w monoterapii wyniósł $75 \%$, w tym $34 \%$ pacjentów uzyskało CR [81]. Odpowiedzi były trwałe $z$ medianami OS oraz PFS wynoszącymi, odpowiednio, 40,5 oraz 9,3 miesiąca [82]. W randomizowanym badaniu III fazy (AETHERA) wykazano, że zastosowanie BV jako leczenia podtrzymującego $\mathrm{w}$ okresie po auto-HSCT (16 cykli) u chorych obarczonych niekorzystnymi czynnikami rokowniczymi (pierwotna oporność, progresja $<12$ mies. od czasu zakończenia leczenia pierwszej linii oraz zajęcie pozawęzłowe przy wznowie choroby) obniża ryzyko progresji choroby o około $50 \%$ [83].

Skojarzenie BV ze schematem ABVD lub ABV w pierwszej linii leczenia HL charakteryzowało się wysoką skutecznością $z$ odsetkami CR, odpowiednio, 95\% oraz 96\%. Ze względu na wysoką toksyczność pulmonologiczną schematu BV-ABVD nie należy stosować BV w połączeniu $z$ bleomycyną [84]. Jest prowadzone randomizowane badanie III fazy służące porównaniu skuteczności schematu BV-ABVD ze skutecznością standardowego leczenia według schematu ABVD (NCT01712490).

Poza zwiększoną toksycznością pulmonologiczną skojarzenia BV z bleomycyną monoterpaia $\mathrm{BV}$ jest $z$ reguły dobrze tolerowana. Do najczęstszych działań niepożądanych należały polineuropatia czuciowa, nudności, zmęczenie, neutropenia oraz biegunki [81]. W trakcie terapii BV obserwowano jednak rzadkie, ale ciężkie powikłania pod postacią rozwoju postępującej leukoencefalopatii wieloogniskowej (PML, progressive multifocal leukoencephalopathy) oraz zapalenia trzustki, występujące przeważnie w okresie trzeciego cyklu leczenia [85-87]. 
Kolejną grupą leków są tak zwane inhibitory punktów kontrolnych reakcji immunologicznej (tzw. immune checkpoint inhibitors). W prawidłowo funkcjonującym organizmie zachowana jest równowaga między czynnikami stymulującymi oraz hamującymi aktywność limfocytów T. Aktywacja receptora programowanej śmierci 1 (PD-1 [programmed death-1], CD279) na błonie komórkowej limfocytów T poprzez wiązanie się do swoich ligandów PD-L1 (programmed death-ligand 1) oraz PD-L2 (programmed death-ligand 2) prowadzi do wzmożenia tolerancji immunologicznej, co zapobiega autoagresji, jednak również osłabia działania przeciwnowotworowe limfocytów T oraz limfocytów naturalnej cytotoksyczności (NK, natural killer). W przypadku HL stwierdzono, że mechanizm ten znacznie przyczynia się do progresji choroby i utrudnia jej zwalczanie przez układ immunologiczny $[4,88]$. Inhibitory PD-1 (niwolumab i pembrolizumab), poprzez blokowanie interakcji receptora PD-1 ze swoimi ligandami, prowadzą do wzmocnienia przeciwnowotworowej reakcji immunologicznej $[89,90]$. Zarówno niwolumab jak i pembrolizumab są przeciwciałami monoklonalnymi wiążącymi się $z$ receptorem $P D-1$ i wykazały wysoką skuteczność w grupie ciężko przeleczonych (w tym po leczeniu BV oraz auto-HSCT) pacjentów $z$ oporną lub nawrotową postacią HL. W badaniu I fazy monoterapia niwolumabem prowadziła do uzyskania odpowiedzi u 20 pacjentów (87\% chorych), przy czym 4 (17\%) osiągnęło CR [90]. $Z$ kolei, stosując pembrolizumab $\mathrm{w}$ grupie 31 pacjentów $\mathrm{z}$ nawrotowym i opornym HL, uzyskano odsetek odpowiedzi sięgający $65 \%$ (48\% odpowiedzi częściowych oraz 16\% CR) [89]. Leczenie jest $z$ reguły dobrze kontrolowane, jednak ze względu na pobudzenie limfocytów T oraz NK w przebiegu leczenia inhibitorami PD-1 może dojść do rozwoju działań niepożądanych na tle wzmożonej reakcji immunologicznej w obrębie płuc (pneumonitis), układu dokrewnego (niedoczynność kory nadnerczy czy przysadki, zapalenie tarczycy), przewodu pokarmowego (colitis oraz zapalenie trzustki) czy skóry (toksyczna nekroliza naskórka) [91]. Oba leki wykazują również skuteczność w nawrocie po allo-HSCT, jednak ich zastosowanie może się wiązać $z$ nasileniem choroby przeszczep przeciwko gospodarzowi (GVHD, graft versus host disease) [92, 93].

\section{Ocena odpowiedzi na leczenie}

Ocena skuteczności leczenia we wczesnych stadiach HL (CS I/II) powinna być przeprowadzona po zakończeniu CTH, a przed rozpoczęciem napromieniania, natomiast w stadiach zaawansowanych
(CS III/IV) - po pierwszych 2 cyklach CTH [9]. Ocenę końcową należy wykonać po zakończeniu leczenia. Powinna ona obejmować badanie przedmiotowe, badania laboratoryjne oraz diagnostykę obrazową za pomocą PET. W celu oceny skuteczności leczenia HL do niedawna stosowano kryteria zaproponowane przez International Workshop to Standardize Response Criteria for Non-Hodgkin Lymphomas z 1999 roku. Kryteria te zostały zaktualizowane przez International Harmonization Project w 2007 roku poprzez włączenie w proces diagnostyczny wyników badań immunohistochemicznych, cytometrii przepływowej i PET. Obecnie stosuje się kryteria zaproponowane przez Międzynarodową Grupę Roboczą w Lugano [28]. Dodatni wynik badania PET po zakończeniu leczenia może ujawnić obecność choroby resztkowej. Trzeba jednak pamiętać o wykluczeniu wyników fałszywie dodatnich, szczególnie jeśli badanie PET wykonano zbyt szybko po zakończeniu terapii $[9,28]$.

\section{Obserwacja po leczeniu}

Wizyty kontrolne powinny się odbywać co 3 miesiące przez pierwsze pół roku po zakończeniu terapii, następnie co 6 miesięcy do 4. roku, a później raz w roku. Wizyta powinna obejmować: wywiad, badanie przedmiotowe, morfologię krwi $z$ rozmazem, OB oraz badania biochemiczne. Badania obrazowe powinny być wykonywane tylko w przypadku wystąpienia objawów klinicznych sugerujących wznowę.

U młodych pacjentów należy kontrolować stężenie hormonów płciowych. Chorzy, którzy byli poddani RTH szyi, wymagają oceny stężenia hormonu tyreotropowego (TSH, thyroid-stimulating hormone) raz w roku przez przynajmniej 2 lata. Podczas wizyt kontrolnych należy zwracać uwagę na objawy związane $z$ późną toksycznością terapii - choroby serca i płuc [45, 94]. Ponadto u pacjentów wyleczonych $z$ HL wyższe jest ryzyko wystąpienia wtórnych nowotworów pod postacią ostrej białaczki szpikowej, nowotworów tkanki łącznej, opłucnej oraz tarczycy czy NHL [45]. Między innymi dlatego u osób napromienianych na śródpiersie powinno się wykonywać regularnie badania radiologiczne klatki piersiowej, a u kobiet także mammografię [94].

\section{Rokowanie}

Rokowanie u chorych na HL jest dobre, a odsetek wyleczeń sięga 80\%. Około 10\% chorych (szczególnie w zaawansowanych stadiach) nie osiąga $\mathrm{CR}$, a u 20-30\% pacjentów, którzy początkowo 
uzyskali odpowiedź na leczenie, dochodzi do nawrotu choroby [9].

\section{Szczególne sytuacje kliniczne}

Chłoniak Hodgkina występuje głównie u osób młodych, a w około $3 \%$ przypadków do zachorowania dochodzi w okresie ciąży. Planując postępowanie terapeutyczne u kobiety w ciąży chorej na HL, należy uwzględnić preferencje pacjentki, dynamikę i zaawansowanie HL oraz czas, jaki pozostał do rozwiązania. W większości przypadków możliwe jest doprowadzenie ciąży do planowego rozwiązania. W celu uniknięcia ekspozycji na promieniowanie jonizujące do oceny stopnia zaawansowania choroby powinno się zastosować rezonans magnetyczny lub ultrasonografię [95]. Choroba rozpoznana w I trymestrze ciąży nie stanowi bezwzględnego wskazania do aborcji. Każda pacjentka powinna być oceniana indywidualnie. We wczesnych stadiach zlokalizowanych powyżej przepony, przy braku cech szybkiej progresji choroby, pacjentka może pozostać pod obserwacją. W przypadku konieczności wdrożenia CTH (obecność objawów B, zaawansowana choroba) można rozważyć stosowanie winblastyny $\mathrm{w}$ monoterapii $\mathrm{w}$ dawce $6 \mathrm{mg} / \mathrm{m}^{2}$ co 2 tygodnie [95, 96]. Alternatywnie można zastosować napromienianie $z$ wykorzystaniem specjalnych osłon na ograniczone pola małą dawką całkowitą (25 Gy). Ponadto można podawać kortykosteroidy, które nie tylko wykazują działanie przeciwchłoniakowe, ale jednocześnie przyspieszają dojrzewanie płodu. Istnieją też dane wskazujące na to, że CTH według protokołu ABVD może być bezpiecznie zastosowana od II trymestru ciąży [96]. Należy dążyć do wcześniejszego porodu, a następnie rozpocząć standardową terapię systemową. U chorej w zaawansowanej ciąży leczenie można odroczyć do czasu porodu w 32.-36. tygodniu. Rokowanie u chorych na HL rozpoznanego w okresie ciąży nie odbiega od rokowania podobnej populacji chorych niebędących w ciąży [95].

\section{Piśmiennictwo}

1. Swerdlow SH, Campo E, Pileri SA, et al. The 2016 revision of the World Health Organization classification of lymphoid neoplasms. Blood. 2016; 127(20): 2375-2390, doi: 10.1182/ /blood-2016-01-643569, indexed in Pubmed: 26980727.

2. Swerdlow SH, Campo E, Harris NL, et al. WHO Classification of Tumours of Haematopoietic and Lymphoid Tissues. Fourth edition. IARC Press, Lyon 2008.

3. Glaser SL, Jarrett RF. The epidemiology of Hodgkin's disease. Baillieres Clin Haematol. 1996; 9(3): 401-416, doi: 10.1016/ /s0950-3536(96)80018-7, indexed in Pubmed: 8922237.
4. Juszczyński P. Mikrośrodowisko komórek Reed-Sternberga w klasycznym chłoniaku Hodgkina - rola patogenetyczna i cel terapeutyczny. Hematologia, 2011. Hematologia. 2011; 2(1): 1-14.

5. Diehl V, Burrichter H, Schaadt M, et al. Hodgkin's disease cell lines: characteristics and biological activities. Haematol Blood Transfus. 1983; 28: 411-417, indexed in Pubmed: 6305805.

6. Irsch J, Nitsch S, Hansmann ML, et al. Isolation of viable Hodgkin and Reed-Sternberg cells from Hodgkin disease tissues. Proc Natl Acad Sci USA. 1998; 95(17): 10117-10122, indexed in Pubmed: 9707610.

7. Döring C, Hansmann ML, Agostinelli C, et al. A novel immunohistochemical classifier to distinguish Hodgkin lymphoma from ALK anaplastic large cell lymphoma. Mod Pathol. 2014; 27(10): 1345-1354, doi: 10.1038/modpathol.2014.44, indexed in Pubmed: 24633193.

8. Pinkus GS, Said JW. Hodgkin's disease, lymphocyte predominance type, nodular - further evidence for a B cell derivation. L \& H variants of Reed-Sternberg cells express L26, a pan B cell marker. Am J Pathol. 1988; 133(2): 211-217.

9. Ansell SM. Hodgkin lymphoma: 2016 update on diagnosis, risk-stratification, and management. Am J Hematol. 2016; 91(4): 434-442, doi: 10.1002/ajh.24272, indexed in Pubmed: 27001163.

10. Savage KJ, Mottok A, Fanale M. Nodular lymphocyte-predominant Hodgkin lymphoma. Semin Hematol. 2016; 53(3): 190 -202, doi: 10.1053/j.seminhematol.2016.05.009, indexed in Pubmed: 27496311.

11. Kanzler H, Küppers R, Hansmann ML, et al. Hodgkin and Reed-Sternberg cells in Hodgkin's disease represent the outgrowth of a dominant tumor clone derived from (crippled) germinal center B cells. J Exp Med. 1996; 184(4): 1495-1505, doi: 10.1084/ /jem.184.4.1495, indexed in Pubmed: 8879220.

12. Kuppers R, Rajewsky K, Zhao M, et al. Hodgkin disease: Hodgkin and Reed-Sternberg cells picked from histological sections show clonal immunoglobulin gene rearrangements and appear to be derived from B cells at various stages of development. Proc Natl Acad Sci USA. 1994; 91(23): 10962-10966, doi: 10.1073/ /pnas.91.23.10962.

13. Küppers R, Rajewsky K, Zhao M, et al. Hodgkin's disease: clonal Ig gene rearrangements in Hodgkin and Reed-Sternberg cells picked from histological sections. Ann NY Acad Sci. 1995; 764: 523-524, doi: 10.1111/j.1749-6632.1995.tb55877.x, indexed in Pubmed: 7486580.

14. Re D, Müschen M, Ahmadi T, et al. Oct-2 and Bob-1 deficiency in Hodgkin and Reed Sternberg cells. Cancer Res. 2001; 61(5): 2080-2084, indexed in Pubmed: 11280769.

15. Stein H, Marafioti T, Foss HD, et al. Down-regulation of BOB.1/ /OBF.1 and Oct2 in classical Hodgkin disease but not in lymphocyte predominant Hodgkin disease correlates with immunoglobulin transcription. Blood. 2001; 97(2): 496-501, doi: 10.1182/blood. v97.2.496, indexed in Pubmed: 11154228.

16. Schwarzer R, Jundt F. Notch and NF- $\kappa B$ signaling pathways in the biology of classical Hodgkin lymphoma. Curr Mol Med. 2011; 11(3): 236-245, doi: 10.2174/156652411795243423, indexed in Pubmed: 21375490.

17. Schwarzer R, Dörken B, Jundt F. Notch is an essential upstream regulator of NF- $\mathrm{BB}$ and is relevant for survival of Hodgkin and Reed-Sternberg cells. Leukemia. 2012; 26(4): 806-813, doi: 10.1038/leu.2011.265, indexed in Pubmed: 21946908.

18. Grufferman S, Cole P, Smith PG, et al. Hodgkin's disease in siblings. N Engl J Med. 1977; 296(5): 248-250, doi: 10.1056/ /NEJM197702032960504, indexed in Pubmed: 831107. 
19. Mack TM, Cozen W, Shibata DK, et al. Concordance for Hodgkin's disease in identical twins suggesting genetic susceptibility to the young-adult form of the disease. N Engl J Med. 1995; 332(7): 413-418, doi: 10.1056/NEJM199502163320701, indexed in Pubmed: 7824015.

20. Horwitz M, Wiernik PH. Pseudoautosomal linkage of Hodgkin disease. Am J Hum Genet. 1999; 65(5): 1413-1422, doi: 10.1086/302608, indexed in Pubmed: 10521308.

21. Azhar M, Din HUd, Muhammad I, et al. Frequency of epstein-barr virus in classical hodgkin Lymphoma. J Ayub Med Coll Abbottabad. 2016; 28(2): 271-275, indexed in Pubmed: 28718560.

22. Weiss LM, Strickler JG, Warnke RA, et al. Epstein-Barr viral DNA in tissues of Hodgkin's disease. Am J Pathol. 1987; 129(1): 86-91, indexed in Pubmed: 2821817.

23. Franceschi S, Dal Maso L, La Vecchia C. Advances in the epidemiology of HIV-associated non-Hodgkin's lymphoma and other lymphoid neoplasms. Int J Cancer. 1999; 83(4): 481-485, doi: 10.1002/ /(sici)1097-0215(19991112)83:4<481::aid-ijc8>3.3.co;2-x, indexed in Pubmed: 10508483.

24. Andrieu JM, Roithmann S, Tourani JM, et al. Hodgkin's disease during HIV1 infection: the French registry experience. French Registry of HIV-associated Tumors. Ann Oncol. 1993; 4(8): 635-641, indexed in Pubmed: 8240994.

25. Tirelli U, Errante D, Dolcetti R, et al. Hodgkin's disease and human immunodeficiency virus infection: clinicopathologic and virologic features of 114 patients from the Italian Cooperative Group on AIDS and Tumors. J Clin Oncol. 1995; 13(7): 1758-1767, doi: 10.1200/JCO.1995.13.7.1758, indexed in Pubmed: 7541452.

26. Diehl V, Sextro M, Franklin J, et al. Clinical presentation, course, and prognostic factors in lymphocyte-predominant Hodgkin's disease and lymphocyte-rich classical Hodgkin's disease: report from the European Task Force on Lymphoma Project on Lymphocyte-Predominant Hodgkin's Disease. J Clin Oncol. 1999; 17(3): 776-783, indexed in Pubmed: 10071266.

27. Barrington SF, Mikhaeel NG, Kostakoglu L, et al. Role of imaging in the staging and response assessment of lymphoma: consensus of the International Conference on Malignant Lymphomas Imaging Working Group. J Clin Oncol. 2014; 32(27): 3048-3058, doi: 10.1200/JCO.2013.53.5229, indexed in Pubmed: 25113771.

28. Cheson BD, Fisher RI, Barrington SF, et al. Alliance, Australasian Leukaemia and Lymphoma Group, Eastern Cooperative Oncology Group, European Mantle Cell Lymphoma Consortium, Italian Lymphoma Foundation, European Organisation for Research, Treatment of Cancer/Dutch Hemato-Oncology Group, Grupo Español de Médula Ósea, German High-Grade Lymphoma Study Group, German Hodgkin's Study Group, Japanese Lymphorra Study Group, Lymphoma Study Association, NCIC Clinical Trials Group, Nordic Lymphoma Study Group, Southwest Oncology Group, United Kingdom National Cancer Research Institute. Recommendations for initial evaluation, staging, and response assessment of Hodgkin and non-Hodgkin lymphoma: the Lugano classification. J Clin Oncol. 2014; 32(27): 3059-3068, doi: 10.1200/JCO.2013.54.8800, indexed in Pubmed: 25113753.

29. Carbone PP, Kaplan HS, Musshoff K, et al. Report of the Committee on Hodgkin's Disease Staging Classification. Cancer Res. 1971; 31(11): 1860-1861, indexed in Pubmed: 5121694.

30. Lister TA, Crowther D, Sutcliffe SB, et al. Report of a committee convened to discuss the evaluation and staging of patients with Hodgkin's disease: Cotswolds meeting. J Clin Oncol. 1989; 7(11): 1630-1636, doi: 10.1200/JCO.1989.7.11.1630, indexed in Pubmed: 2809679.
31. Jerusalem G, Beguin Y, Fassotte MF, et al. Whole-body positron emission tomography using $18 \mathrm{~F}$-fluorodeoxyglucose compared to standard procedures for staging patients with Hodgkin's disease. Haematologica. 2001; 86(3): 266-273, indexed in Pubmed: 11255273.

32. Gallamini A, Hutchings M, Rigacci L, et al. Early interim 2-[18F] fluoro-2-deoxy-D-glucose positron emission tomography is prognostically superior to International Prognostic Score in advanced-stage Hodgkin's lymphoma: a report from a Joint Italian-Danish Study. J Clin Oncol. 2007; 25(24): 3746-3752, doi: 10.1200/ /jco.2007.11.6525.

33. Tubiana M. Toward comprehensive management tailored to prognostic factors of patients with clinical stages I and II in Hodgkin's disease. The EORTC Lymphoma Group controlled clinical trials: 1964-1987. Blood. 1989; 73(1): 47-56.

34. Diehl V, Stein H, Hummel M, et al. Hodgkin's lymphoma: biology and treatment strategies for primary, refractory, and relapsed disease. Hematology Am Soc Hematol Educ Program. 2003: 225-247, doi: 10.1182/asheducation-2003.1.225, indexed in Pubmed: 14633784.

35. Hasenclever D, Diehl V, Armitage J, et al. A prognostic score for advanced Hodgkin's disease. N Engl J Med. 1998; 339(21): 1506-1514, doi: 10.1056/nejm199811193392104.

36. Hutchings M, Loft A, Hansen M, et al. FDG-PET after two cycles of chemotherapy predicts treatment failure and progression-free survival in Hodgkin lymphoma. Blood. 2006; 107(1): 52-59, doi: 10.1182/blood-2005-06-2252, indexed in Pubmed: 16150944.

37. Mikhaeel NG, Hutchings M, Fields PA, et al. FDG-PET after two to three cycles of chemotherapy predicts progression-free and overall survival in high-grade non-Hodgkin lymphoma. Ann Oncol. 2005; 16(9): 1514-1523, doi: 10.1093/annonc/mdi272, indexed in Pubmed: 15980161.

38. Coyle M, Kostakoglu L, Evens AM. The evolving role of response-adapted PET imaging in Hodgkin lymphoma. Ther Adv Hematol. 2016; 7(2): 108-125, doi: 10.1177/2040620715625615, indexed in Pubmed: 27054026.

39. Radford J, Illidge T, Counsell N, et al. Results of a trial of PET-directed therapy for early-stage Hodgkin's lymphoma. N Engl J Med. 2015; 372(17): 1598-1607, doi: 10.1056/NEJMoa1408648, indexed in Pubmed: 25901426.

40. André MPE, Girinsky T, Federico M, et al. Early positron emission tomography response-adapted treatment in stage I and II Hodgkin lymphoma: final results of the randomized EORTC/LYSA/FIL H10 trial. J Clin Oncol. 2017; 35(16): 1786-1794, doi: 10.1200/JC0.2016.68.6394, indexed in Pubmed: 28291393.

41. Engert A, Franklin J, Eich HT, et al. Two cycles of doxorubicin, bleomycin, vinblastine, and dacarbazine plus extended-field radiotherapy is superior to radiotherapy alone in early favorable Hodgkin's lymphoma: final results of the GHSG HD7 trial. J Clin Oncol. 2007; 25(23): 3495-3502, doi: 10.1200/JCO.2006.07.0482, indexed in Pubmed: 17606976.

42. Engert A, Plütschow A, Eich HT, et al. Reduced treatment intensity in patients with early-stage Hodgkin's lymphoma. N Engl J Med. 2010; 363(7): 640-652, doi: 10.1056/NEJMoa1000067, indexed in Pubmed: 20818855.

43. Eich H, Diehl V, Görgen H, et al. Intensified chemotherapy and dose-reduced involved-field radiotherapy in patients with early unfavorable Hodgkin's lymphoma: final analysis of the German Hodgkin Study Group HD11 trial. J Clin Oncol. 2010; 28(27): 4199-4206, doi: 10.1200/jco.2010.29.8018. 
44. von Tresckow B, Plütschow A, Fuchs M, et al. Dose-intensification in early unfavorable Hodgkin's lymphoma: final analysis of the German Hodgkin Study Group HD14 trial. J Clin Oncol. 2012; 30(9): 907-913, doi: 10.1200/JCO.2011.38.5807, indexed in Pubmed: 22271480 .

45. van Leeuwen FE, Ng AK. Late sequelae in Hodgkin lymphoma survivors. Hematol Oncol. 2017; 35(Suppl 1): 60-66, doi: 10.1002/ /hon.2402, indexed in Pubmed: 28591411.

46. Canellos GP, Anderson JR, Propert KJ, et al. Chemotherapy of advanced Hodgkin's disease with MOPP, ABVD, or MOPP alternating with ABVD. N Engl J Med. 1992; 327(21): 1478-1484, doi: 10.1056/NEJM199211193272102, indexed in Pubmed: 1383821.

47. Viviani S, Bonadonna G, Santoro A, et al. Alternating versus hybrid MOPP and ABVD combinations in advanced Hodgkin's disease: ten-year results. J Clin Oncol. 1996; 14(5): 1421-1430, doi: 10.1200/JCO.1996.14.5.1421, indexed in Pubmed: 8622055 .

48. Duggan DB, Petroni GR, Johnson JL, et al. Randomized comparison of ABVD and MOPP/ABV hybrid for the treatment of advanced Hodgkin's disease: report of an intergroup trial. J Clin Oncol. 2003; 21(4): 607-614, doi: 10.1200/JCO.2003.12.086, indexed in Pubmed: 12586796.

49. Engert A, Haverkamp H, Kobe C, et al. German Hodgkin Study Group, Swiss Group for Clinical Cancer Research, Arbeitsgemeinschaft Medikamentöse Tumortherapie. Reduced-intensity chemotherapy and PET-guided radiotherapy in patients with advanced stage Hodgkin's lymphoma (HD15 trial): a randomised, open-label, phase 3 non-inferiority trial. Lancet. 2012; 379(9828): 1791-1799, doi: 10.1016/S0140-6736(11)61940-5, indexed in Pubmed: 22480758.

50. Diehl V, Sieber M, Rüffer U, et al. BEACOPP: an intensified chemotherapy regimen in advanced Hodgkin's disease. The German Hodgkin's Lymphoma Study Group. Ann Oncol. 1997; 8(2): 143-148, indexed in Pubmed: 9093722.

51. Skoetz N, Trelle S, Rancea M, et al. Effect of initial treatment strategy on survival of patients with advanced-stage Hodgkin's lymphoma: a systematic review and network meta-analysis. Lancet Oncol. 2013; 14(10): 943-952, doi: 10.1016/S1470-2045(13)70341-3, indexed in Pubmed: 23948348.

52. Viviani S, Zinzani PL, Rambaldi A, et al. Michelangelo Foundation, Gruppo Italiano di Terapie Innovative nei Linfomi, Intergruppo Italiano Linfomi. ABVD versus BEACOPP for Hodgkin's lymphoma when high-dose salvage is planned. N Engl J Med. 2011; 365(3): 203-212, doi: 10.1056/NEJMoa1100340, indexed in Pubmed: 21774708 .

53. Eichenauer DA, Thielen I, Haverkamp H, et al. Therapy-related acute myeloid leukemia and myelodysplastic syndromes in patients with Hodgkin lymphoma: a report from the German Hodgkin Study Group. Blood. 2014; 123(11): 1658-1664, doi: 10.1182/ /blood-2013-07-512657, indexed in Pubmed: 24478403.

54. Engert A, Diehl V, Franklin J, et al. Escalated-dose BEACOPP in the treatment of patients with advanced-stage Hodgkin's lymphoma: 10 years of follow-up of the GHSG HD9 study. J Clin Oncol. 2009; 27(27): 4548-4554, doi: 10.1200/JCO.2008.19.8820, indexed in Pubmed: 19704068.

55. Behringer K, Breuer K, Reineke T, et al. German Hodgkin's Lymphoma Study Group. Secondary amenorrhea after Hodgkin's lymphoma is influenced by age at treatment, stage of disease, chemotherapy regimen, and the use of oral contraceptives during therapy: a report from the German Hodgkin's Lymphoma
Study Group. J Clin Oncol. 2005; 23(30): 7555-7564, doi: 10.1200/ /JCO.2005.08.138, indexed in Pubmed: 16234521.

56. Van der Kaaij MA, et al. Gonadal function in males after chemotherapy for early-stage Hodgkin's lymphoma treated in four subsequent trials by the European Organisation for Research and Treatment of Cancer: EORTC Lymphoma Group and the Groupe d'Étude des Lymphomes de l'Adulte. J Clin Oncol. 2007; 25(19): 2825-2832.

57. Nogová L, Reineke T, Eich HT, et al. Extended field radiotherapy, combined modality treatment or involved field radiotherapy for patients with stage IA lymphocyte-predominant Hodgkin's lymphoma: a retrospective analysis from the German Hodgkin Study Group (GHSG). Ann Oncol. 2005; 16(10): 1683-1687, doi: 10.1093/annonc/mdi323, indexed in Pubmed: 16093276.

58. Nogová L, Reineke T, Brillant C, et al. German Hodgkin Study Group. Lymphocyte-predominant and classical Hodgkin's lymphoma: a comprehensive analysis from the German Hodgkin Study Group. J Clin Oncol. 2008; 26(3): 434-439, doi: 10.1200/ /JCO.2007.11.8869, indexed in Pubmed: 18086799.

59. Advani RH, Horning SJ, Hoppe RT, et al. Mature results of a phase II study of rituximab therapy for nodular lymphocyte-predominant Hodgkin lymphoma. J Clin Oncol. 2014; 32(9): 912-918, doi: 10.1200/JCO.2013.53.2069, indexed in Pubmed: 24516013.

60. Cencini E, Fabbri A, Bocchia M. Rituximab plus ABVD in newly diagnosed nodular lymphocyte-predominant Hodgkin lymphoma. Br J Haematol. 2017; 176(5): 831-833, doi: 10.1111/bjh.14001, indexed in Pubmed: 26913966.

61. Smardova L, Engert A, Haverkamp H, et al. Successful mobilization of peripheral blood stem cells with the DHAP regimen (dexamethasone, cytarabine, cisplatinum) plus granulocyte colony-stimulating factor in patients with relapsed Hodgkin's disease. Leuk Lymphoma. 2005; 46(7): 1017-1022, doi: 10.1080/10428190500064276, indexed in Pubmed: 16019552.

62. Mehrzad V, Ashrafi F, Farrashi AR, et al. Comparison of ifosfamide, carboplatin and etoposide versus etoposide, steroid, and cytarabine cisplatin as salvage chemotherapy in patients with refractory or relapsed Hodgkin's lymphoma. Adv Biomed Res. 2017; 6: 30, doi: 10.4103/2277-9175.201687, indexed in Pubmed: 28401077.

63. Labrador J, Cabrero-Calvo M, Pérez-López E, et al. ESHAP as salvage therapy for relapsed or refractory Hodgkin's lymphoma. Ann Hematol. 2014; 93(10): 1745-1753, doi: 10.1007/s00277-014-2114-0, indexed in Pubmed: 24863692.

64. Rodriguez J, Rodriguez MA, Fayad L, et al. ASHAP: a regimen for cytoreduction of refractory or recurrent Hodgkin's disease. Blood. 1999; 93(11): 3632-3636, indexed in Pubmed: 10339468.

65. Magagnoli M, Spina M, Balzarotti M, et al. IGEV regimen and a fixed dose of lenograstim: an effective mobilization regimen in pretreated Hodgkin's lymphoma patients. Bone Marrow Transplant. 2007; 40(11): 1019-1025, doi: 10.1038/sj.bmt.1705862, indexed in Pubmed: 17906705.

66. Bartlett NL, Niedzwiecki D, Johnson JL, et al. Cancer Leukemia Group B. Gemcitabine, vinorelbine, and pegylated liposomal doxorubicin (GVD), a salvage regimen in relapsed Hodgkin's lymphoma: CALGB 59804. Ann Oncol. 2007; 18(6): 1071-1079, doi: 10.1093/annonc/mdm090, indexed in Pubmed: 17426059.

67. Baetz T, Belch A, Couban S, et al. Gemcitabine, dexamethasone and cisplatin is an active and non-toxic chemotherapy regimen in relapsed or refractory Hodgkin's disease: a phase II study by the National Cancer Institute of Canada Clinical Trials Group. Ann Oncol. 2003; 14(12): 1762-1767, doi: 10.1093/annonc/mdg496, indexed in Pubmed: 14630682. 
68. Josting A, Kàtay I, Rueffer U, et al. Favorable outcome of patients with relapsed or refractory Hodgkin's disease treated with high-dose chemotherapy and stem cell rescue at the time of maximal response to conventional salvage therapy (Dex-BEAM). Ann Oncol. 1998; 9(3): 289-295, doi: 10.1023/a:1008283909959, indexed in Pubmed: 9602263.

69. Moreau P, Fleury J, Brice P, et al. Early intensive therapy with autologous stem cell transplantation in advanced Hodgkin's disease: retrospective analysis of 158 cases from the French registry. Bone Marrow Transplant. 1998; 21(8): 787-793, indexed in Pubmed: 9603402.

70. Brice P, Bouabdallah R, Moreau P, et al. Prognostic factors for survival after high-dose therapy and autologous stem cell transplantation for patients with relapsing Hodgkin's disease: analysis of 280 patients from the French registry. Société Française de Greffe de Moëlle. Bone Marrow Transplant. 1997; 20(1): 21-26, doi: 10.1038/sj.bmt.1700838, indexed in Pubmed: 9232251.

71. Schmitz N, Pfistner B, Sextro M, et al. Aggressive conventional chemotherapy compared with high-dose chemotherapy with autologous haemopoietic stem-cell transplantation for relapsed chemosensitive Hodgkin's disease: a randomised trial. Lancet. 2002; 359(9323): 2065-2071, doi: 10.1016/s0140-6736(02)08938-9.

72. Kusnierz-Glaz CR, Schlegel PG, Wong RM, et al. Influence of age on the outcome of 500 autologous bone marrow transplant procedures for hematologic malignancies. J Clin Oncol. 1997; 15(1): 18-25, doi: 10.1200/JCO.1997.15.1.18, indexed in Pubmed: 8996120.

73. Brice P, Divine M, Simon D, et al. Feasibility of tandem autologous stem-cell transplantation (ASCT) in induction failure or very unfavorable (UF) relapse from Hodgkin's disease (HD). SFGM/ /GELA Study Group. Ann Oncol. 1999; 10(12): 1485-1488, indexed in Pubmed: 10643540

74. Sureda A, Robinson S, Canals C, et al. Reduced-intensity conditioning compared with conventional allogeneic stem-cell transplantation in relapsed or refractory Hodgkin's lymphoma: an analysis from the Lymphoma Working Party of the European Group for Blood and Marrow Transplantation. J Clin Oncol. 2008; 26(3): 455-462, doi: 10.1200/JC0.2007.13.2415, indexed in Pubmed: 18086796.

75. Robinson SP, Sureda A, Canals C, et al. Lymphoma Working Party of the EBMT. Reduced intensity conditioning allogeneic stem cell transplantation for Hodgkin's lymphoma: identification of prognostic factors predicting outcome. Haematologica. 2009; 94(2): 230-238, doi: 10.3324/haematol.13441, indexed in Pubmed: 19066328.

76. Schmitz N, Sureda A, Robinson S. Allogeneic transplantation of hematopoietic stem cells after nonmyeloablative conditioning for Hodgkin's disease: indications and results. Semin Oncol. 2004; 31(1): 27-32, doi: 10.1053/j.seminoncol.2003.10.018.

77. Gonzalez VJ. Role of radiation therapy in the treatment of Hodgkin lymphoma. Curr Hematol Malig Rep. 2017; 12(3): 244-250, doi: 10.1007/s11899-017-0385-y, indexed in Pubmed: 28497317.

78. Devizzi L, Santoro A, Bonfante V, et al. Vinorelbine: a new promising drug in Hodgkin's disease. Leuk Lymphoma. 1996; 22(5-6): 409-414, doi: 10.3109/10428199609054778, indexed in Pubmed: 8882953.

79. Santoro A, Bredenfeld H, Devizzi L, et al. Gemcitabine in the treatment of refractory Hodgkin's disease: results of a multicenter phase II study. J Clin Oncol. 2000; 18(13): 2615-2619, doi: 10.1200/JC0.2000.18.13.2615, indexed in Pubmed: 10893294.
80. Younes A, Bartlett NL, Leonard JP, et al. Brentuximab vedotin (SGN-35) for relapsed CD30-positive lymphomas. N Engl J Med. 2010; 363(19): 1812-1821, doi: 10.1056/NEJMoa1002965, indexed in Pubmed: 21047225.

81. Younes A, Gopal AK, Smith SE, et al. Results of a pivotal phase II study of brentuximab vedotin for patients with relapsed or refractory Hodgkin's lymphoma. J Clin Oncol. 2012; 30(18): 2183-2189, doi: 10.1200/JC0.2011.38.0410, indexed in Pubmed: 22454421 .

82. Gopal AK, Chen R, Smith SE, et al. Durable remissions in a pivotal phase 2 study of brentuximab vedotin in relapsed or refractory Hodgkin lymphoma. Blood. 2015; 125(8): 1236-1243, doi: 10.1182/ /blood-2014-08-595801, indexed in Pubmed: 25533035.

83. Moskowitz CH, Nademanee A, Masszi T, et al. AETHERA Study Group. Brentuximab vedotin as consolidation therapy after autologous stem-cell transplantation in patients with Hodgkin's lymphoma at risk of relapse or progression (AETHERA): a randomised, double-blind, placebo-controlled, phase 3 trial. Lancet. 2015; 385(9980): 1853-1862, doi: 10.1016/S0140-6736(15)60165-9, indexed in Pubmed: 25796459.

84. Younes A, Connors JM, Park SI, et al. Brentuximab vedotin combined with ABVD or AVD for patients with newly diagnosed Hodgkin's lymphoma: a phase 1, open-label, dose-escalation study. Lancet Oncol. 2013; 14(13): 1348-1356, doi: 10.1016/ /S1470-2045(13)70501-1, indexed in Pubmed: 24239220.

85. Carson K, Newsome S, Kim E, et al. Progressive multifocal leukoencephalopathy associated with brentuximab vedotin therapy: A report of 5 cases from the Southern Network on Adverse Reactions (SONAR) project. Cancer. 2014; 120(16): 2464-2471, doi: $10.1002 /$ cncr.28712.

86. von Geldern G, Pardo CA, Calabresi PA, et al. PML-IRIS in a patient treated with brentuximab. Neurology. 2012; 79(20): 2075-2077, doi: 10.1212/WNL.0b013e3182749f17, indexed in Pubmed: 23115213.

87. Gandhi MD, Evens AM, Fenske TS, et al. Pancreatitis in patients treated with brentuximab vedotin: a previously unrecognized serious adverse event. Blood. 2014; 123(18): 2895-2897, doi: 10.1182/ /blood-2014-03-561878, indexed in Pubmed: 24786458.

88. Yamamoto R, Nishikori M, Kitawaki T, et al. PD-1-PD-1 ligand interaction contributes to immunosuppressive microenvironment of Hodgkin lymphoma. Blood. 2008; 111(6): 3220-3224, doi: 10.1182/ /blood-2007-05-085159, indexed in Pubmed: 18203952.

89. Armand P, Shipp MA, Ribrag V, et al. Programmed death-1 blockade with pembrolizumab in patients with classical Hodgkin lymphoma after brentuximab vedotin failure. J Clin Oncol. 2016 [Epub ahead of print], indexed in Pubmed: 27354476.

90. Younes A, Santoro A, Shipp M, et al. Nivolumab for classical Hodgkin's lymphoma after failure of both autologous stem-cell transplantation and brentuximab vedotin: a multicentre, multicohort, single-arm phase 2 trial. Lancet Oncol. 2016; 17(9): 1283-1294, doi: 10.1016/S1470-2045(16)30167-X, indexed in Pubmed: 27451390.

91. Villasboas JC, Ansell SM. Recent advances in the management of Hodgkin lymphoma. F1000Res. 2016; 5, doi: 10.12688/f1000research.8301.1, indexed in Pubmed: 27158471.

92. Bond DA, Alinari L. Emerging treatment options for the management of Hodgkin's lymphoma: clinical utility of nivolumab. J Blood Med. 2017; 8: 41-54, doi: 10.2147/JBM.S117452, indexed in Pubmed: 28546779.

93. Maly J, Alinari L. Pembrolizumab in classical Hodgkin's lymphoma. Eur J Haematol. 2016; 97(3): 219-227, doi: 10.1111/ /ejh.12770, indexed in Pubmed: 27147112. 
94. $\mathrm{Ng} \mathrm{AK}$, van Leeuwen FE. Hodgkin lymphoma: late effects of treatment and guidelines for surveillance. Semin Hematol. 2016; 53(3): 209-215, indexed in Pubmed: 27496313.

95. Moshe Y, Bentur OS, Lishner M, et al. The management of Hodgkin lymphomas in pregnancies. Eur J Haematol. 2017 [Epub ahead of print], doi: 10.1111/ejh.12956, indexed in Pubmed: 28850718.
96. Azim HA, Pavlidis N, Peccatori FA. Treatment of the pregnant mother with cancer: a systematic review on the use of cytotoxic, endocrine, targeted agents and immunotherapy during pregnancy. Part II: Hematological tumors. Cancer Treat Rev. 2010; 36(2): 110-121, doi: 10.1016/j.ctrv.2009.11.004, indexed in Pubmed: 20018452. 